\title{
DETERMINAN IMPLEMENTASI AKUNTANSI UMKM DI YOGYAKARTA
}

\author{
Muklis Al Amin \\ Universitas Mahakarya Asia,Yogyakarta \\ muklisalamin18@gmail.com \\ Sungkono \\ Universitas Janabadra, Yogyakarta \\ sengkuni.senggono@gmail.com \\ I Made Laut Mertha Jaya \\ Universitas Mahakarya Asia,Yogyakarta \\ mad.jaya@yahoo.com \\ Disubmit : 13 Agustus 2021 \\ Direview : 4 Oktober 2021 \\ Diterima : 29 November 2021
}

\begin{abstract}
Indonesia is a country whose economy is mostly supported by the MSME sector. This study aims to identify and analyze the factors that influence the implementation of MSME accounting in the Special Region of Yogyakarta. The population of this research is the managers/owners of MSMEs in the Special Region of Yogyakarta. The sample of this study was 100 respondents who were obtained by the Quota Sampling method. The variables of this study consisted of education level, business scale, length of business and accounting training. The data test method uses multiple linear regression analysis. The findings of this study indicate that the variables of education level and length of business have no effect on the application of accounting to SMEs. While the business scale and accounting training have a significant effect on the application of accounting to SMEs in Yogyakarta. The results of this study can be a reference for the government or related agencies in conducting an approach to socializing the importance of preparing financial reports for the development and continuity of a business activity, especially MSMEs in D.I.Yogyakarta.
\end{abstract}

Keywrods: Application Of MSME Accounting; MSME Accounting.

\section{Abstrak}

Indonesia merupakan negara yang perekonomiannya paling banyak ditumpu dari sektor UMKM. Penelitian ini bertujuan untuk mengidentifikasi dan menganalisis faktor-faktor yang mempengaruhi implementasi akuntansi UMKM di Daerah Istimewa Yogyakarta. Populasi penelitian ini adalah para pengelola/pemilik UMKM di Daerah Istimewa Yogyakarta. Sampel penelitian ini sebanyak 100 responden yang diperoleh dengan metode Quota Sampling. Variabel penelitian ini terdiri dari tingkat pendidikan, skala usaha, lama usaha dan pelatihan akuntansi. Metode uji datanya menggunakan analisis regresi linier berganda. Temuan penelitian ini menunjukkan bahwa variabel tingkat pendidikan dan lama usaha tidak berpengaruh terhadap penerapan akuntansi pada UMKM. Sedangkan skala usaha dan pelatihan akuntansi berpengaruh signifikan terhadap penerapan akuntansi pada UMKM di Yogyakarta. Hasil 
penelitian ini dapat menjadi acuan bagi pemerintah atau instansi terkait dalam melakukan pendekatan sosialisasi pentingnya penyusunan laporan keuangan bagi perkembangan dan kelangsungan suatu kegiatan usaha khususnya UMKM di D.I.Yogyakarta.

Kata Kunci: Implementasi Akuntansi UMKM; Akuntansi UMKM.

\section{PENDAHULUAN}

Usaha mikro, kecil dan menengah (UMKM) merupakan bisnis yang produktif yang digerakan oleh perorangan atau badan usaha. UMKM merupakan sektor usaha yang tangguh dan berperan penting bagi perkembangan perekonomian indonesia. Salah satu wujud kontribusi besar UMKM pada perekonomian indonesia ditunjukkan melalui pencapaian Product Domestic Bruto (PDB) Indonesia setiap tahunnya.

Tabel 1. Kontribusi UMKM terhadap PDB Indonesia (dalam rupiah)

\begin{tabular}{|c|c|c|c|c|c|}
\hline \multirow{2}{*}{ No. } & \multirow{2}{*}{ Skala Usaha } & \multicolumn{2}{|l|}{2016} & \multicolumn{2}{|l|}{2017} \\
\hline & & Kontribusi & $\%$ & Kontribusi & $\%$ \\
\hline 1. & Usaha Kecil & 1.128.056.8 Milyar & 9.63 & 1.234.210.7 Milyar & 9.61 \\
\hline 2. & Usaha Mikro & 4.292.287.8 Milyar & 36.65 & 4.727.989.9 Milyar & 36.83 \\
\hline 3. & Usaha Menengah & 1.588.938.3 Milyar & 13.57 & 1.742.435.7 Milyar & 13,57 \\
\hline & $\underline{\text { Total UMKM }}$ & 7.009.283.0 Milyar & $\underline{59.84}$ & 7.704.635.9 Milyar & $\underline{60,000}$ \\
\hline 4. & Usaha Besar & 4.703.167.6 Milyar & 40.16 & 5.136.223.1 Milyar & 40,00 \\
\hline
\end{tabular}

Sumber : Kementrian Koperasi dan UMKM, 2019.

Kementerian Perindustrian juga mengakui bahwa UMKM menjadi sektor yang paling penting bagi perekonomian Indonesia terutama kemampuan daya serap tenaga kerjanya. Data terakhir menunjukkan bahwa serapan tenaga kerja yang dihasilkan dari UMKM adalah sebanyak 97,22\%. UMKM menjadi kekuatan terbesar dalam perekonomian Indonesia, namun banyak tugas yang harus dilakukan para pelaku UMKM untuk semakin berkembang dan mampu bersaing hingga pada kancah internasional. Pengembangan UMKM bagi perekonomian di Indonesia dapat mendorong pertumbuhan investasi di dalam negeri. Hal ini tentu dapat menciptakan lapangan kerja dan investasi nasional (Tedjasuksmana, 2014).

D.I.Yogyakarta yang merupakan kota pelajar, kota budaya sekaligus kota pariwisata, saat ini telah mulai muncul bisnis UMKM yang terus berkembang. UMKM di berbagai cabang industri telah menjadi pendorong perputaran perekonomian masyarakat di D.I.Yogyakarta. Perkembangan sektor UMKM di D.I.Yogyakarta bertujuan untuk mengurangi tingkat pengangguran dan mendongkrak kesejahteraan masyarakat (Sujarweni \& Jaya, 2019a). Berdasarkan data dari Dinas Koperasi dan UMKM DIY pada tahun 2017, sebaran jumlah pelaku UMKM di Provinsi D.I.Yogyakarta, yaitu 14\% di Kota Yogyakarta, 18\% di Kabupaten Sleman, 26\% di Kabupaten Bantul, 20\% di Kabupaten Kulonprogo dan 22\% di Kabupaten Gunungkidul. Besarnya perkembangan kewirausahaan melalui Usaha Mikro Kecil Menengah (UMKM) juga meningkatkan daya kreatifitas dan kemampuan masyarakat untuk mampu mengelola dan memanfaatkan sumber daya alam yang tersedia dengan baik dan tepat guna (Tedjasuksmana, 2014).

Akuntansi merupakan sarana pendukung yang dapat digunakan oleh UMKM ketika mengelola keuangan perusahaannya (I. M. L. (STIE B. Y. Mertha Jaya, 2019). Akuntansi juga 
berfungsi untuk mendistribusikan informasi mengenai transaksi kepada personel operasional entitas guna kelancaran tugas-tugas penting mereka (I. M. L. (STIE B. Y. Mertha Jaya, 2019). Berdasarkan data yang dihimpun dari tribunjogja.com diketahui bahwa sekitar $20 \%$ dari pelaku UMKM yang telah melakukan pembukuan keuangan untuk kegiatan usahanya, selebihnya sebanyak $80 \%$ pelaku UMKM belum mampu menyusun laporan keuangan yang sesuai standar peraturan akuntansi keuangan. Kewajiban penyelenggaraan akuntansi bagi usaha kecil sebenarnya telah tersirat dalam Undang-Undang Usaha Kecil No. 9 Tahun 1995 dan UndangUndang Perpajakan (I. M. L. (STIE B. Y. Mertha Jaya, 2019). Pemerintah maupun komunitas akuntansi juga telah menegaskan pentingnya pencatatan dan penyelengaraan akuntansi bagi usaha kecil, seperti UMKM. Adanya SAK EMKM merupakan salah satu cerminan dari upaya pemerintah mempermudah dalam menyusun laporan keuangan. Standar Akuntansi Keuangan Entitas Mikro, Kecil, dan Menengah (SAK EMKM) merupakan standar akuntansi yang ditujukan untuk entitas usaha baik usaha mikro, kecil, dan menengah. SAK ini disusun dan diterbitkan oleh Dewan Standar Akuntansi Keuangan Ikatan Akuntan Indonesia (DSAK IAI) pada tahun 2016 dan mulai berlaku efektif per 1 Januari 2018 (Ikatan Akuntan Indonesia, 2018). Penyediaan informasi akuntansi bagi UMKM melalui laporan keuangan sangat diperlukan untuk akses subsidi pemerintah dan akses tambahan modal bagi usaha kecil melalui perbankan (Sujarweni \& Jaya, 2019b).

Berdasarkan data dari Bank Indonesia (BI) tahun 2019, jumlah kredit bermasalah (NPL) pada UMKM meningkat pada awal tahun 2019. Pada Januari 2019 tingkat presentase NPL di sektor ini mencapai 3,79\% atau naik jika dibandingkan Desember 2018 yang saat itu hanya sebesar 3,44\%. Besarnya persentase NPL akan membuat bank lebih memperketat seleksi penyaluran kredit bagi pelaku UMKM yang pantas untuk menerima dana pinjaman, sehingga pelaku UMKM akan semakin sulit untuk mendapatkan modal dari kredit usahanya. Jika catatan keuangan serta laporan keuangan yang dimiliki oleh pelaku UMKM tidak sesuai standar PSAK, maka dapat dipastikan akan sulit untuk memperoleh kredit modal usaha. Ketidakmampuan pelaku UMKM untuk melakukan pencatatan keuangan yang baik disebabkan oleh kurangnya pengetahuan mengenai penyusunan laporan keuangan yang sesuai standar PSAK (I. made laut Mertha Jaya \& Ilahiyah, 2020). Hal ini membuat peneliti ingin menggali lebih dalam faktorfaktor penentu yang membuat pelaku UMKM terutama di D.I.Yogyakrta dapat melakukan penerapan akuntansi serta menyusun laporan keuangan sesuai PSAK bagi kegiatan bisnisnya.

Beberapa literatur lainnya juga menjelaskan bahwa skala usaha, lamanya usaha dan pelatihan akuntansi berpengaruh positif terhadap cangkupan penggunaan informasi akuntansi (Sungkono, 2010; Kurniawati, Nugroho dan Arifin, 2012). Skala usaha merupakan salah satu indikasi perkembangan suatu perusahaan dimana perusahaan yang besar akan membawa dampak bagi karyawan yang terlibat didalamnya. Bertambahnya karyawan dari tahun ketahun menandakan perusahaan tumbuh dan berkembang dikarenakan perusahaan yang besar akan membutuhkan karyawan dengan jumlah yang besar pula (Sujarweni \& Jaya, 2019b). UMKM yang sudah lama berjalan juga mengindikasikan bahwa kebutuhan untuk menerapkan akuntansi keuangan dan informasi akuntansi untuk penyusunan laporan keuangan juga sangat diperlukan karena memiliki kompleksitas yang juga semakin tinggi (Finishia dan Suzan, 2019). Hasil temuan ini berbeda dengan Koesmeliana dan Dewi (2015); Astiani dan Sagoro (2018) yang menjelaskan bahwa tidak terdapat pengaruh positif antara skala usaha terhadap penggunaan informasi akuntansi, tetapi presepsi pelaku UMKM tentang akuntansi, dan pengetahuan akuntansi justru berpengaruh positif terhadap penggunaan informasi akuntansi. Perbedaan temuan ini menimbulkan research gap yang perlu adanya pembuktian kembali, sehingga kami menggunakan variabel ini untuk diuji kembali. 
Penelitian Sinarwati, (2014) bahkan menemukan faktor lain seperti ketidaksiapan, infrastruktur, dan kekurangan sumber daya manusia yang dominan menghambat susahnya penerapan akuntansi bagi UMKM. Hasil lainnya juga menemukan bahwa latar belakang pendidikan dan jenjang pendidikan tidak berpengaruh signifikan, tetapi lamanya usaha yang berpengaruh signifikan terhadap pemahaman UMKM dalam menyusun laporan keuangan (Kurniawati, Nugroho dan Arifin, 2012; Sitoresmi dan Fuad, 2013; Tuti dan Dwijayanti, 2016). Pendidikan menggambarkan proses seseorang untuk meningkatkan pengetahuan, kemampuan teknis serta kemampuan organisasinya (Sujarweni \& Jaya, 2019b). Pendidikan yang rendah akan membuat pelaku usaha kesulitan ketika menerapkan akuntansi keuangan pada usaha mereka karena kurangnya pemahaman. Peningkatan pendidikan bagi pelaku UMKM ini juga dapat dilakukan melalui peningkatan pelatihan akuntansi (Solovia, 2010; Sujarweni dan Jaya, 2019; Jaya dan Ilahiyah, 2020). Semakin sering kegiatan pelatihan yang diberikan kepada pelaku UMKM, maka semakin meningkat pula pengetahuan mengenai akuntansi dan pentingnya penyusunan laporan keuangan.

Berdasarkan research gap dan fenomena tersebut, maka kami melakukan penelitian ini dengan memfokuskan pada faktor yang paling menentukan dan mempengaruhi penerapan akuntansi pada UMKM dengan menggunakan indikator variabel seperti jenjang pendidikan, latar belakang pendidikan, lamanya usaha, dan ukuran usaha pada UMKM di D.I.Yogyakarta. Maka dari itu disusunlah beberapa hipotesis untuk diuji lebih lanjut sebagai berikut.

$\mathbf{H}_{1}$ : Jenjang pendidikan berpengaruh secara positif dan signifikan terhadap penerapan akuntansi pada pelaku UMKM di D.I.Yogyakarta

$\mathbf{H}_{2}$ : Skala Usaha berpengaruh secara positif dan signifikan terhadap penerapan akuntansi pada pelaku UMKM di D.I.Yogyakarta

$\mathbf{H}_{3}$ : Lama Usaha berpengaruh secara positif dan signifikan terhadap penerapan akuntansi pada pelaku UMKM di D.I.Yogyakarta

$\mathbf{H}_{4}$ : Pelatihan Akuntansi berpengaruh secara positif dan signifikan terhadap penerapan akuntansi pada pelaku UMKM di D.I.Yogyakarta

\section{METODE PENELITIAN}

Metode penelitian ini termasuk penelitian kuantitatif dengan menggunakan teknik pengumpulan sampelnya menggunakan kuesioner. Survey menggunakan kuesioner disebarkan langsung kepada pemilik/manajer UMKM di Provinsi Daerah Istimewa Yogyakarta secara acak. Objek penelitian ini adalah pelaku UMKM yang berada di Provinsi Daerah Istimewa Yogyakarta, yang terdiri dari 4 Kabupaten dan 1 Kota Madya, yaitu Kab. Sleman, Kab. Bantul, Kab. Gunungkidul, Kab. Kulonprogo dan Kota Yogyakarta. Penelitian ini telah dilaksanakan sejak Desember 2019 hingga April 2020. Populasi penelitian ini adalah pelaku UMKM yang berada di Provinsi D.I.Yogyakarta yang jumlahnya belum diketahui secara pasti. Data populasi yang belum diketahui membuat kami menggunakan rumus Lemeshow untuk menentukan banyaknya sampel penelitian ini. Berikut ini rumus Lameshow yang digunakan (Ogston, Lemeshow, Hosmer, Klar, \& Lwanga, 1991):

Keterangan :

$$
n=\frac{Z_{1}-\alpha /{ }_{2} P(1-P)}{d^{2}}
$$

$$
\begin{array}{cl}
n & =\text { Jumlah sampel } \\
z & =\text { skor } \mathrm{z} \text { pada kepercayaan } 95 \%=1,96 \\
p & =\text { maksimal estimasi }=0,5 \\
d & =\text { alpha }(0,10) \text { atau sampling eror }=10 \% \\
\text { Melalui rumus di atas, maka jumlah sampel yang akan diambil adalah }
\end{array}
$$




$$
\begin{aligned}
& n=\frac{Z_{1}-\alpha /{ }_{2} P(1-P)}{d^{2}} \\
& n=\frac{1,96^{2} \cdot 0,5(1-0,5)}{0,1^{2}} \\
& n=\frac{3,8416 \cdot 0,25}{0.01} \\
& n=96,04=100
\end{aligned}
$$

Sehingga, banyaknya "n" (sampel) yang didapatkan adalah 96,04. Hasil ini dibulatkan menjadi 100 pelaku UMKM, sehingga sampel penelitian ini sebanyak 100 pelaku UMKM seD.I.Yogyakarta. Data yang digunakan pada penelitian ini adalah data primer dan data sekunder. Data primer berupa kuisioner dan dokumentasi yang diperoleh dari para pelaku UMKM di D.I.Yogyakarta. Sedangkan data sekunder yang digunakan berupa data yang dipublikasi dan diperoleh dari lembaga atau badan, seperti jurnal dan buku.

Teknik pengumpulan data yang digunakan yaitu menggunakan kuesioner. Kuesioner disebarkan secara langsung kepada para pelaku UMKM di Provinsi Daerah Istimewa Yogyakarta secara acak. Responden diberikan waktu untuk mengisi kuesioner yang dibagikan dan dikumpulkan kembali oleh peneliti. Penilaian dari setiap jawaban yang diberikan oleh responden, peneliti menggunakan skala likert. Bobot penilaian skala likert yaitu SS (sangat setuju dinilai dengan skor 5), $\mathbf{S}$ (setuju dinilai dengan skor 4), $\mathbf{N}$ (netral dinilai dengan skor 3), TS (tidak setuju dinilai dengan skor 2), STS (sangat tidak setuju dinilai dengan skor 1). Peneliti

\begin{tabular}{|c|c|c|}
\hline Variabel & Indikator variabel & $\begin{array}{c}\text { Jumlah } \\
\text { Pertanyaan }\end{array}$ \\
\hline \multirow{3}{*}{$\begin{array}{l}\text { Jenjang } \\
\text { Pendidikan } \\
\left(\mathbf{X}_{1}\right)\end{array}$} & Kemampuan teknis dalam penerapan akuntansi & \multirow{3}{*}{$1,2,3,4,5,6$} \\
\hline & Kemampuan perusahaan dalam mengelola akuntansi & \\
\hline & $\begin{array}{l}\text { Pengetahuan dalam penerapan akuntansi menunjang } \\
\text { perkembangan bagi perusahaan (Finishia, et al., 2019). }\end{array}$ & \\
\hline \multirow{3}{*}{$\begin{array}{l}\text { Skala Usaha } \\
\left(\mathrm{X}_{2}\right)\end{array}$} & Jumlah karyawan yang banyak dalam pengambilan kebijakan. & \multirow{3}{*}{$7,8,9,10,11$} \\
\hline & Usaha ditunjang dengan adanya penerapan akuntansi & \\
\hline & Inisiatif untuk menerapkan akuntansi (Finishia, et al., 2019). & \\
\hline \multirow{3}{*}{$\begin{array}{l}\text { Lama Usaha } \\
\left(\mathrm{X}_{3}\right)\end{array}$} & Umur usaha cukup dalam penerapan akuntansi & \multirow{3}{*}{$12,13,14,15,16$} \\
\hline & $\begin{array}{l}\text { Perusahaan sudah menggunakan pencatatan akuntansi sebagai } \\
\text { dasar pengambilan keputusan }\end{array}$ & \\
\hline & $\begin{array}{l}\text { Laporan keuangan sudah lama diterapkan perusahaan (Finishia, et } \\
\text { al., 2019). }\end{array}$ & \\
\hline \multirow{3}{*}{$\begin{array}{l}\text { Pelatihan } \\
\text { Akuntansi } \\
\left(\mathrm{X}_{4}\right)\end{array}$} & Para pengusaha pernah mengikuti pelatihan akuntansi & \multirow{3}{*}{$17,18,19,20,21,22$} \\
\hline & Pelatihan akuntansi sangat berguna bagi perusahaan & \\
\hline & $\begin{array}{l}\text { Menerapkan ilmu pelatihan akuntansi dalam perusahaan (Andriani, } \\
\text { et al. 2014). }\end{array}$ & \\
\hline \multirow{3}{*}{$\begin{array}{l}\text { Penerapan } \\
\text { Akuntansi } \\
\text { (Y) }\end{array}$} & Penerapkan laporan keuangan & \multirow{3}{*}{$\begin{array}{l}23,24,25,26,27 \\
28,29,30,31\end{array}$} \\
\hline & Penggunakan laporan keuangan & \\
\hline & $\begin{array}{l}\text { Laporan keuangan sangat menunjang perkembangan } \\
\text { perusahaan (Kurniawati, et al. 2012). }\end{array}$ & \\
\hline
\end{tabular}
juga menggunakan media online untuk memperoleh data berupa jurnal ilmiah lain yang berkaitan dengan penelitian ini.

Tabel 2. Definisi operasional dan pengukuran variabel penelitian 
Data yang sudah terkumpul selanjutnya dianalisis menggunakan beberapa uji, seperti uji statistik deskriptif yang berguna untuk membantu dalam meringkas perbandingan beberapa variabel data skala dalam satu tabel serta dapat digunakan melakukan pengamatan penyimpangan data, uji validitas dan uji reliabilitas, uji validitas merupakan uji yang bertujuan untuk menilai suatu alat ukur dalam mengukur ketepatan dengan apa yang seharusnya diukur. Sedangkan uji reliabilitas digunakan untuk mengukur suatu kuesioner yang merupakan indikator dari variabel atau konstruk. Selanjutnya, uji asumsi klasik (uji normalitas, uji multikolinearitas, uji heteroskedastisitas dan uji autokorelasi). Uji normalitas berguna untuk mengetahui apakah variabel dependen, independen, atau keduanya berdistribusi normal, mendekati normal atau tidak. Uji multikolinearitas bertujuan untuk mendeteksi adanya korelasi antar variabel independen dalam model regresi, dimana model regresi dikatakan baik jika tidak terjadi korelasi di antara variabel independen. Uji heteroskedastisitas bertujuan untuk menguji apakah dalam model regresi terjadi ketidaksamaan varian dari residual satu pengamatan yang lain tetap. Uji autokorelasi bertujuan untuk menguji apakah dalam model regresi linier ada korelasi antara residual periode $t$ dengan residual pada periode $t-1$ (periode sebelumnya).

Selanjutnya, dilaukan uji t atau uji pengaruh antara variabel independen dan variabel dependen secara parsial. Uji kelayakan model atau uji F dilakukan untuk mengetahui bahwa model regresi yang digunakan sudah layak atau belum dalam menjelaskan persamaan variabel yang diteliti. Uji final, yaitu uji regresi linier berganda, dan uji koefisien determinasi $\left(\mathrm{R}^{2}\right)$. Analisis regresi linier berganda digunakan untuk mengetahui pengaruh dari variabel independen terhadap variabel dependen dalam suatu persamaan linear (Jaya, 2020). Uji koefisien determinasi dilakukan untuk mengukur besarnya kemampuan model untuk menerangkan variabel dependennya. Persamaan uji regresi berganda penelitian ini sebagai berikut:

$Y=\alpha+\beta_{1} X_{1}+\beta_{2} X_{2}+\beta_{3} X_{3}+\beta_{4} X_{4}+\varepsilon$

\section{Keterangan: \\ Y : Variabel dependen penerapan Akuntansi UMKM \\ $\alpha \quad$ : Bilangan Koefisien regresi Kostanta \\ $\beta_{1}, \beta_{2}, \beta_{3}, \beta_{4} \quad$ : Koefisien regresi dari masing-masing proksi \\ $\mathrm{X}_{1} \quad$ : Variabel Jenjang Pendidikan \\ $\mathrm{X}_{2} \quad$ : Variabel Skala Usaha \\ $\mathrm{X}_{3} \quad$ : Variabel Lama Usaha \\ $\mathbf{X}_{4} \quad$ : Variabel Pelatihan Akuntansi \\ $\varepsilon \quad$ : Eror Term atau Residual}

\section{HASIL DAN PEMBAHASAN}

Distribusi sampel pada tabel 3 menunjukan kuesioner yang disebarkan berjumlah 120, sedangkan yang layak untuk dijadikan data penelitian dan dianalisis yaitu 100 kuisioner dikarenakan 20 kuesioner lainnya tidak diisi lengkap.

Tabel 3. Distribusi kuesioner penelitian

\begin{tabular}{lcc}
\hline \multicolumn{1}{c}{ Keterangan } & Jumlah & Presentase \\
\hline Kuesioner yang disebar & 120 & $100 \%$ \\
\hline Kuesioner yang tidak diisi lengkap & 20 & $17 \%$ \\
\hline Kuesioner yang digunakan & 100 & $83 \%$ \\
\hline
\end{tabular}

Sumber: Hasil olah data primer, 2020. 
Tabel 4. Klasifikasi Responden berdasarkan jenis kelamin

\begin{tabular}{ccc}
\hline \multicolumn{1}{c}{ Jenis Kelamin } & Jumlah & Presentase \\
\hline Laki-laki & 43 & $43 \%$ \\
\hline Perempuan & 57 & $57 \%$ \\
\hline Jumlah & & $\mathbf{1 0 0 \%}$ \\
\hline
\end{tabular}

Sumber: Hasil olah data primer, 2020.

Berdasarkan tabel 4. diketahui bahwa dari 100 responden yanng menjadi subjek penelitian, responden dengan jenis kelamin laki-laki lebih dominan daripada perempuan yaitu 57 orang atau 57\%, Sedangkan responden perempuan sebanyak 43 orang atau $43 \%$. Hal ini menunjukkan bahwa responden pelaku UMKM dengan jenis kelamin laki-laki lebih dominan dibanding responden perempuan.

Tabel 5. Klasifikasi Responden Berdasarkan Usia Pelaku UMKM

\begin{tabular}{ccc}
\hline Usia & Jumlah & Presentase \\
\hline 17-25 Tahun & 27 & $27 \%$ \\
\hline 25-30 Tahun & 42 & $42 \%$ \\
\hline 30-40 Tahun & 20 & $20 \%$ \\
\hline$>40$ Tahun & 11 & $11 \%$ \\
\hline Jumlah & $\mathbf{1 0 0}$ & $\mathbf{1 0 0 \%}$ \\
\hline
\end{tabular}

Sumber: Hasil olah data primer, 2020.

Berdasarkan tabel 5 dapat diketahui bahwa responden yang memiliki usia antara 17-25 tahun, yaitu sebanyak 27 responden atau 27\%. Kemudian usia antara 25-30 tahun sebanyak 42 responden atau 42\%. Sedangkan usia antara 30-40 tahun sebanyak 20 responden atau 20\%, serta responden yang memiliki usia lebih dari 40 tahun sebanyak 11 responden atau $11 \%$. Responden berumur 25-30 tahun adalah responden yang paling dominan karena saat peneliti menyebar kuesioner, peneliti lebih banyak menjumpai responden yang berumur 25-30 tahun.

Tabel 6. Klasifikasi Responden Berdasarkan Jenjang Pendidikan

\begin{tabular}{ccc}
\hline Jenjang Pendidikan & Jumlah & Presentase \\
\hline SD & - & - \\
\hline SMP & 4 & $4 \%$ \\
\hline SMA/SMK & 49 & $49 \%$ \\
\hline D3 & 7 & $7 \%$ \\
\hline S1 & 39 & $39 \%$ \\
\hline S2 & 1 & $1 \%$ \\
\hline Jumlah & $\mathbf{1 0 0}$ & $\mathbf{1 0 0 \%}$ \\
\hline
\end{tabular}

Sumber: Hasil olah data primer, 2020.

Berdasarkan tabel 6 dapat diketahui bahwa jenjang pendidikan responden tingkat SMP sebanyak 4 orang atau $4 \%$, jenjang pendidikan responden tingkat SMA/SMK sebanyak 49 orang atau $49 \%$, jenjang pendidikan responden tingkat D3 sebanyak 7 orang atau $7 \%$, jenjang pendidikan responden tingkat S1 sebanyak 39 orang atau 39\% dan untuk jenjang pendidikan responden S2 sebanyak 1 orang atau 1\%. Pada penelitian ini tidak terdapat responden yang memiliki jenjang pendidikan SD. 
Tabel 7. Klasifikasi Responden Berdasarkan Badan Hukum Usaha

\begin{tabular}{|c|c|c|}
\hline Badan Hukum Usaha & Jumlah & Presentase \\
\hline Perorangan & 97 & $97 \%$ \\
\hline Sekutu (CV/Firma) & 1 & $1 \%$ \\
\hline PT & 2 & $2 \%$ \\
\hline Koperasi & - & - \\
\hline Jumlah & 100 & $100 \%$ \\
\hline
\end{tabular}

Sumber: Hasil olah data primer, 2020.

Berdasarkan tabel 4.5. dapat diketahui bahwa mayoritas badan hukum responden adalah Perorangan, yaitu bentuk badan hukum responden Perorangan sebanyak 97 orang atau 97\%, bentuk badan hukum Sekutu (CV/Firma) sebanyak 1 orang atau 1\% dan bentuk badan hukum PT sebanyak 2 orang atau $2 \%$. Pada penelitian ini tidak terdapat responden yang berbadan hukum Koperasi.

Tabel 8. Klasifikasi Responden Berdasarkan Lama Usaha

\begin{tabular}{ccc}
\hline Lama Usaha & Jumlah & Presentase \\
\hline$<$ 1Tahun & 6 & $6 \%$ \\
\hline 2 Tahun & 16 & $16 \%$ \\
\hline 3 Tahun & 20 & $20 \%$ \\
\hline 4 Tahun & 22 & $22 \%$ \\
\hline$>$ 5Tahun & 36 & $36 \%$ \\
\hline Jumlah & $\mathbf{1 0 0}$ & $\mathbf{1 0 0 \%}$ \\
\hline
\end{tabular}

Sumber: Hasil olah data primer, 2020.

Berdasarkan tabel 4.6. menunjukan bahwa responden berdasarkan lama usaha kurang dari 1 tahun sebanyak 6 orang atau 6\%, lama usaha responden 2 tahun sebanyak 16 orang atau $16 \%$, lama usaha responden 3 tahun sebanyak 20 orang atau 20\%, lama usaha responden 4 tahun sebanyak 22 orang atau $22 \%$ dan untuk lama usaha responden lebih dari 5 tahun sebanyak 36 orang atau 36\%. Pada penelitian ini mayoritas responden memiliki lama usaha lebih dari 5 tahun.

Tabel 9. Klasifikasi Responden Berdasarkan Jenis Usaha

\begin{tabular}{lccc}
\hline \multicolumn{1}{c}{ Jenis Usaha } & Jumlah & Presentase \\
\hline Jasa & 25 & $25 \%$ \\
\hline Dagang & 74 & $74 \%$ \\
\hline Manufaktur & 1 & $1 \%$ \\
\hline \multicolumn{2}{c}{ Jumlah } & $\mathbf{1 0 0}$ & $\mathbf{1 0 0 \%}$ \\
\hline
\end{tabular}

Sumber: Hasil olah data primer, 2020.

Berdasarkan tabel 9 karakteristik responden berdasarkan jenis usaha menunjukan bahwa jenis usaha dalam bentuk Jasa sebanyak 25 orang atau $25 \%$, jenis usaha dalam bentuk Dagang sebanyak 74 orang atau 74\% dan jenis usaha dalam bentuk Manufaktur sebanyak 1 orang atau 1\%. Dalam penelitian ini mayoritas jenis usaha responden adalah dalam bentuk Dagang.

Tabel 10. Klasifikasi Responden Berdasarkan Modal Usaha

\begin{tabular}{lcc}
\hline \multicolumn{1}{c}{ Modal Usaha } & Jumlah & Presentase \\
\hline Kurang dari 50 Juta & 54 & $54 \%$ \\
\hline 50 Juta sampai 100 Juta & 34 & $34 \%$ \\
\hline Lebih dari 100 Juta & 12 & $12 \%$ \\
\hline Jumlah & $\mathbf{1 0 0}$ & $\mathbf{1 0 0 \%}$ \\
\hline
\end{tabular}

Sumber: Hasil olah data primer, 2020. 
Berdasarkan tabel 4.8. karakteristik responden berdasarkan modal usaha menunjukan bahwa modal usaha kurang dari 50 juta sebanyak 54 orang atau 54\%, modal usaha antara 50 juta sampai 100 juta sebanyak 34 orang atau 34\% dan modal usaha lebih dari 100 juta sebanyak 12 orang atau $12 \%$. Dalam penelitian ini mayoritas modal usaha responden adalah kurang dari 50 juta.

Statistik deskriptif bertujuan untuk memberikan deskripsi/gambaran suatu data dari masing-masing variabel secara umum yang dilihat dari nilai maksimum, nilai minimum, ratarata (mean), median, dan standar deviasi. Analisis statistik deskriptif diperoleh hasil yang dapat dilihat pada tabel 11 .

Tabel 11. Statistik Deskriptif

\begin{tabular}{lc|c|c|c|c}
\hline & $\mathrm{N}$ & Minimum & Maximum & Mean & Std. Deviation \\
\hline PENDIDIKAN & 100 & 10 & 30 & 21,05 & 4,356 \\
\hline SKALA USAHA & 100 & 11 & 25 & 19,57 & 3,439 \\
\hline LAMA USAHA & 100 & 9 & 25 & 17,32 & 4,052 \\
\hline PELATIHAN AKUNTANSI & 100 & 6 & 30 & 21,32 & 4,530 \\
\hline PENERAPAN AKUNTANSI & 100 & 6 & 30 & 21,66 & 4,497 \\
\hline
\end{tabular}

Sumber : Hasil olah data primer, 2020.

Berdasarkan hasil statistik deskriptif di atas, terdapat informasi terkait hasil analisis deskriptif yang dapat dijabarkan sebagai berikut.

\section{a. Jenjang Pendidikan}

Hasil analisis statistik deskriptif pada variabel jenjang pendidikan menunjukkan bahwa nilai minimal responden sebesar 10 dan nilai maksimal responden sebesar 30 sedangkan nilai rata-rata (mean) sebesar 21,05 dan standar deviasi sebesar 4,356.

\section{b. Skala Usaha}

Hasil analisis statistik deskriptif pada variabel jenjang pendidikan menunjukkan bahwa nilai minimal responden sebesar 11 dan nilai makasimal responden sebesar 25, sedangka nilai rata-rata (mean) sebesar 19,57 nilai dan standar deviasi sebesar 3,439.

\section{c. Lama Usaha}

Hasil analisis statistik deskriptif pada variabel jenjang pendidikan menunjukkan bahwa nilai minimal responden sebesar 9 dan nilai makasimal responden sebesar 25 , sedangkan nilai rata-rata (mean) sebesar 17,32 dan standar deviasi sebesar 4,052.

\section{d. Pelatihan Akuntansi}

Hasil analisis statistik deskriptif pada variabel jenjang pendidikan menunjukkan bahwa nilai minimal responden sebesar 6 dan nilai makasimal responden sebesar 30, sedangkan nilai rata-rata (mean) sebesar 21, dan standar deviasi sebesar 4,530.

\section{e. Penerapan Akuntansi}

Hasil analisis statistik deskriptif pada variabel jenjang pendidikan menunjukkan bahwa nilai minimal responden sebesar 6 dan nilai makasimal responden sebesar 30, sedangkan nilai rata-rata (mean) sebesar 21, dan standar deviasi sebesar 4,497.

\section{Uji Validitas}

Pengujian validitas dilakukan dengan melihat nilai signifikansi variabel dari masingmasing item pertanyaan dengan variabel total, dikatakan valid jika nilai sig. $<0.05$. Hasilnya sebagai berikut. 
Tabel 12. Hasil Uji Validitas Variabel Penelitian

\begin{tabular}{|c|c|c|c|c|}
\hline Variabel & Item & R-hitung & R-tabel & Keterangan \\
\hline \multirow{6}{*}{$\begin{array}{c}\text { Jenjang } \\
\text { Pendidikan } \\
\left(\mathrm{X}_{1}\right)\end{array}$} & $\mathrm{X}_{1.1}$ & 0,684 & 0,195 & Valid \\
\hline & $\mathrm{X}_{1.2}$ & 0,788 & 0,195 & Valid \\
\hline & $\mathrm{X}_{1.3}$ & 0,769 & 0,195 & Valid \\
\hline & $\mathrm{X}_{1.4}$ & 0,805 & 0,195 & Valid \\
\hline & $\mathrm{X}_{1.5}$ & 0,765 & 0,195 & Valid \\
\hline & $\mathrm{X}_{1.6}$ & 0,787 & 0,195 & Valid \\
\hline Variabel & Item & R-hitung & R-tabel & Keterangan \\
\hline \multirow{5}{*}{$\begin{array}{l}\text { Skala Usaha } \\
\left(\mathrm{X}_{2}\right)\end{array}$} & $\mathrm{X}_{2.1}$ & 0,706 & 0,195 & Valid \\
\hline & $\mathrm{X}_{2.2}$ & 0,836 & 0,195 & Valid \\
\hline & $\mathrm{X}_{2.3}$ & 0,817 & 0,195 & Valid \\
\hline & $\mathrm{X}_{2.4}$ & 0,787 & 0,195 & Valid \\
\hline & $\mathrm{X}_{2.5}$ & 0,710 & 0,195 & Valid \\
\hline Variabel & Item & R-hitung & R-tabel & Keterangan \\
\hline \multirow{5}{*}{$\begin{array}{l}\text { Lama Usaha } \\
\qquad\left(\mathrm{X}_{3}\right)\end{array}$} & $\mathrm{X}_{3.1}$ & 0,712 & 0,195 & Valid \\
\hline & $\mathrm{X}_{3.2}$ & 0,757 & 0,195 & Valid \\
\hline & $\mathrm{X}_{3.3}$ & 0,893 & 0,195 & Valid \\
\hline & $\mathrm{X}_{3.4}$ & 0,878 & 0,195 & Valid \\
\hline & $\mathrm{X}_{3.5}$ & 0,832 & 0,195 & Valid \\
\hline Variabel & Item & R-hitung & R-tabel & Keterangan \\
\hline \multirow{6}{*}{$\begin{array}{l}\text { Pelatihan } \\
\text { Akuntansi } \\
\quad\left(\mathrm{X}_{4}\right)\end{array}$} & $\mathrm{X} 4.1$ & 0,694 & 0,195 & Valid \\
\hline & $\mathrm{X}_{4.2}$ & 0,789 & 0,195 & Valid \\
\hline & $\mathrm{X}_{4.3}$ & 0,837 & 0,195 & Valid \\
\hline & $\mathrm{X}_{4.4}$ & 0,835 & 0,195 & Valid \\
\hline & $\mathrm{X}_{4.5}$ & 0,791 & 0,195 & Valid \\
\hline & $\mathrm{X}_{4.6}$ & 0,838 & 0,195 & Valid \\
\hline Variabel & Item & R-hitung & R-tabel & Keterangan \\
\hline \multirow{9}{*}{$\begin{array}{l}\text { Penerapan } \\
\text { Akuntansi } \\
\text { (Y) }\end{array}$} & $\mathrm{Y}_{1.1}$ & 0,578 & 0,195 & Valid \\
\hline & $Y_{1.2}$ & 0,365 & 0,195 & Valid \\
\hline & $Y_{1.3}$ & 0,631 & 0,195 & Valid \\
\hline & $Y_{1.4}$ & 0,774 & 0,195 & Valid \\
\hline & $Y_{1.5}$ & 0,772 & 0,195 & Valid \\
\hline & $Y_{1.6}$ & 0,768 & 0,195 & Valid \\
\hline & $Y_{1.7}$ & 0,772 & 0,195 & Valid \\
\hline & $\mathrm{Y}_{1.8}$ & 0,706 & 0,195 & Valid \\
\hline & $Y_{1.9}$ & 0,547 & 0,195 & Valid \\
\hline
\end{tabular}

Sumber: Hasil olah data primer, 2020.

Berdasarkan hasil uji validitas yang ditunjukan pada tabel 12, dapat diketahui pada setiap butir penyataan kuesioner menunjukkan bahwa nilai R-hitung (Rxy) > Rtabel $(0,195)$. Hasil ini menunjukkan bahwa secara keseluruhan 31 butir pernyataan telah valid.

\section{Uji Reliabilitas}

Uji reliabilitas penelitian ini menggunakan One Shoot dimana suatu variabel dianggap reliable jika nilai Conbach's Alpha >0.70. Hasil ujinya sebagai berikut. 
Tabel 13. Hasil Uji Reliabilitas

\begin{tabular}{cccc}
\hline Variabel & Conbach's Alpha & Pembanding & Keterangan \\
\hline $\mathrm{X}_{1}$ & 0,906 & 0,6 & Realiabel \\
\hline $\mathrm{X}_{2}$ & 0,895 & 0,6 & Realiabel \\
\hline $\mathrm{X}_{3}$ & 0,921 & 0,6 & Realiabel \\
\hline $\mathrm{X}_{4}$ & 0,885 & 0,6 & Realiabel \\
\hline $\mathrm{Y}$ & 0,766 & 0,6 & Realiabel \\
\hline
\end{tabular}

Sumber: Hasil olah data promer, 2020.

Berdasarkan hasil uji reabilitas yang ditunjukkan pada tabel 4.6, dapat disimpulkan bahwa variabel skala usaha, umur perusahaan, pendidikan, pelatihan akuntansi, dan penggunaan informasi akuntansi yang digunakan dalam penelitian ini telah andal atau reliable, hal ini bisa dilihat dari nilai Cronbach's Alpha pada variabel jenjang pendidikan ( $\left.\mathrm{X}_{1}\right)$, skala usaha $\left(\mathrm{X}_{2}\right)$, lama usaha $\left(\mathrm{X}_{3}\right)$, pelatihan akuntansi $\left(\mathrm{X}_{4}\right)$, dan penerapan akuntansi (Y) lebih besar dari 0,70 sehingga kuesioner layak digunakan dalam penelitian ini

\section{Uji Normalitas}

Uji normalitas data berguna untuk mengetahui apakah variabel dependen, independen, atau keduanya berdistribusi normal, mendekati normal atau tidak. Uji normalitas menggunakan uji statistik Kolmogorof Smirnov (K-S), Jika nilai test statistic $\geq 0,05$ maka data residual berdistribusi normal dan juga sebaliknya. Hasil ujinya sebagai berikut.

Tabel 14. Hasil Uji Normalitas

\begin{tabular}{|c|c|c|}
\hline \multicolumn{3}{|c|}{ One-Sample Kolmogorov-Smirnov Test } \\
\hline & & Unstandardized Residual \\
\hline \multicolumn{2}{|l|}{$\mathrm{N}$} & 100 \\
\hline \multirow{2}{*}{ Normal Parameters } & Mean & ,0000000 \\
\hline & Std. Deviation & 3,10456147 \\
\hline \multirow[t]{3}{*}{ Most Extreme Differences } & Absolute & 063 \\
\hline & Positive &, 048 \\
\hline & Negative &,- 063 \\
\hline \multicolumn{2}{|l|}{ Test Statistic } & ,063 \\
\hline \multicolumn{2}{|l|}{ Asymp. Sig. (2-tailed) } & $200^{\mathrm{c}, \mathrm{d}}$ \\
\hline \multicolumn{3}{|c|}{ a. Test distribution is Normal. } \\
\hline \multicolumn{3}{|l|}{ b. Calculated from data. } \\
\hline \multicolumn{3}{|c|}{ c. Lilliefors Significance Correction. } \\
\hline \multicolumn{3}{|c|}{ d. This is a lower bound of the true significance. } \\
\hline
\end{tabular}

Sumber: Hasil olah data primer, 2020.

Berdasarkan hasil uji normalitas menunjukkan bahwa nilai Asymp. Sig. Residual sebesar 0,200. Hasil ini menunjukkan bahwa nilai Asymp. Sig. Residual $(0,200)>0,05$, sehingga distribusi data residual regresi adalah normal.

\section{Uji Multikolinearitas}

Uji multikolinearitas bertujuan untuk mendeteksi adanya korelasi antar variabel independen dalam model regresi, dimana model regresi dikatakan baik jika tidak terjadi korelasi di antara variabel independen. Uji asumsi klasik multikoliniearitas ditentukan menggunakan besaran nilai tolerance (a) dengan variance inflation factor (VIF) dengan tingkat nilai alpha/tolerance $=10 \%$ atau 0,10 atau VIF $=10$. Apabila nilai tolerance lebih dari 0.10 atau nilai VIF kurang dari 10, maka dapat dinyatakan bebas dari kasus multikolineritas. Hasil pengujiannya sebagai berikut. 
Tabel 15. Hasil Uji Multikolinieritas

\begin{tabular}{lcc}
\hline \multicolumn{1}{c}{ Model } & \multicolumn{2}{c}{ Collinearity Statistics } \\
\cline { 2 - 3 } & Tolerance & VIF \\
\hline Jenjang Pendidikan $\left(\mathrm{X}_{1}\right)$ & 0,414 & 2,417 \\
\hline Skala Usaha $\left(\mathrm{X}_{2}\right)$ & 0,424 & 2,359 \\
\hline Lama Usaha $\left(\mathrm{X}_{3}\right)$ & 0,394 & 2,540 \\
\hline Pelatihan Akuntansi $\left(\mathrm{X}_{4}\right)$ & 0,677 & 1,478 \\
\hline
\end{tabular}

Departemen Variabel : Penerapan Akuntansi (Y)

Sumber: Hasil olah data primer, 2020.

Berdasarkan hasil uji multikolinearitas diketahui bahwa nilai Tolerance pada keempat variabel independen yaitu Jenjang Pendidikan $\left(\mathrm{X}_{1}\right)$, Skala Usaha $\left(\mathrm{X}_{2}\right)$, Lama Usaha $\left(\mathrm{X}_{3}\right)$, dan Pelatihan Akuntansi $\left(\mathrm{X}_{4}\right)>0,10$ dengan nilai VIF $<10$. Dengan demikian dapat disimpulkan bahwa semua variabel bebas layak digunakan dalam penelitian karena data tidak terdapat masalah multikolineritas antar variabel.

\section{Uji Heteroskedastisitas}

Uji heteroskedastisitas bertujuan untuk menguji apakah dalam model regresi terjadi ketidaksamaan varian dari residual satu pengamatan yang lain tetap, maka disebut Homoskedastisitas dan jika berbeda maka disebut Heteroskedastisitas. Uji heteroskedastisitas penelitian ini menggunakan kriteria, sebagai berikut 1) Jika nilai signifikansi lebih besar dari alpha $(\alpha) 0.05$, kesimpulannya adalah tidak terjadi heteroskedastisitas. 2) Jika nilai signifikansi lebih kecil dari alpha $(\alpha) 0.05$, kesimpulannya adalah terjadi heteroskedastisitas. Berdasarkan hasil uji yang telah dilakukan, diperoleh hasil output sebagai berikut.

Tabel 16. Hasil Uji Heteroskedastisitas

\begin{tabular}{|c|c|c|c|c|c|}
\hline \multirow[b]{2}{*}{ Model } & \multicolumn{2}{|c|}{$\begin{array}{l}\text { Unstandardized } \\
\text { Coefficients }\end{array}$} & \multirow{2}{*}{$\begin{array}{c}\text { Standardized } \\
\text { Coefficients } \\
\text { Beta }\end{array}$} & \multirow[b]{2}{*}{$\mathrm{t}$} & \multirow[b]{2}{*}{ Sig. } \\
\hline & B & Std. Error & & & \\
\hline 1 (Constant) & 1,796 & 1,217 & & 1,476 &, 143 \\
\hline Jenjang Pendidikan (X1) & , 106 & ,070 & 236 & 1,513 & ,134 \\
\hline Skala Usaha (X2) &,- 001 & ,088 &,- 001 &,- 007 & ,995 \\
\hline Lama Usaha (X3) &,- 011 & ,077 &,- 024 &,- 149 & ,882 \\
\hline Pelatihan Akuntansi (X4) &,- 066 & ,053 &,- 154 & $-1,262$ &, 210 \\
\hline a. Dependent Variable: RES2 & & & & & \\
\hline
\end{tabular}

Sumber: Hasil olah data primer, 2020.

Berdasarkan dari hasil uji heteroskedastisitas menggunakan uji glejser pada tabel 16 hasil signifikansi dari variabel bebas atau varibel $\mathrm{X}_{1}$ sebesar 0.134 , variabel $\mathrm{X}_{2}$ sebesar 0.995 , variabel $\mathrm{X}_{3}$ sebesar 0.882 dan variabel $\mathrm{X}_{4}$ sebesar 0,210 atau di atas dari nilai standar signifikansi 0.05 , sehingga dapat disimpulkan bahwa antara variabel independen tidak terjadi masalah heteroskedastisitas.

\section{Uji Autokorelasi}

Uji autokorelasi bertujuan untuk menguji apakah dalam model regresi linier ada korelasi antara residual periode $\mathrm{t}$ dengan residual pada periode $\mathrm{t}-1$ (periode sebelumnya). Model regresi yang baik adalah yang bebas dari autokorelasi (Ghozali, 2013). Untuk mendeteksi ada tidaknya autokorelasi dalam penelitian ini digunakan uji Durbin-Watson (DW Test). Berikut ini adalah hasil ujinya. 
Tabel 17. Hasil Uji Autokorelasi

\begin{tabular}{llrrrr}
\hline Model & $\mathrm{R}$ & $\mathrm{R}$ Square & $\begin{array}{c}\text { Adjusted } \mathrm{R} \\
\text { Square }\end{array}$ & $\begin{array}{c}\text { Std. Error of } \\
\text { the Estimate }\end{array}$ & Durbin-Watson \\
\hline 1 &, $724^{\mathrm{a}}$ &, 523 &, 503 & 3,16925 & 2,076 \\
\hline a. Predictors: (Constant), Pelatihan Akuntansi $\left(\mathrm{X}_{1}\right)$, Jenjang Pendidikan $\left(\mathrm{X}_{2}\right)$, \\
Saka Usaha $\left(\mathrm{X}_{3}\right)$, Lama Usaha $\left(\mathrm{X}_{4}\right)$ \\
b. Dependent Variable: Penerapan Akuntansi $(\mathrm{Y})$ \\
Sumber: Hasil olah data primer, 2020.
\end{tabular}

Pada output data di atas, nilai D-W yaitu 2,076 Hasil ini memunculkan nilai dL dan dU yang diperoleh dari tabel Durbin Watson, dengan ketentuan, yaitu: $K=4$ dan $n=100$. Kemudian diperoleh nilai dL sebesar 1,5922 dan nilai dU sebesar 1,7582 Pengambilan keputusan didasarkan pasa rumusan sebagai berikut :

1. Tidak terjadi autokorelasi jika DL $<(4-D W)>D U$

2. Terjadi autokorelasi posotif jika DW $<\mathrm{dL}$

3. Terjadi autokorelasi negatif jika DW > (4-dU)

Tabel 18. Nilai Durbin Watson

\begin{tabular}{cccccc}
\hline $\mathrm{dL}$ & $\mathrm{dU}$ & $4-\mathrm{dU}$ & $4-\mathrm{dL}$ & $\mathrm{DW}$ & $4-\mathrm{DW}$ \\
\hline 1,5922 & 1,7582 & 2,2418 & 2,4078 & 2,076 & 1,924 \\
\hline
\end{tabular}

Sumber: Hasil olah data primer, 2020.

Dengan demikian tidak ada korelasi serial diantara disturbance terms, sehingga variabel independen tidak ada autokorelasi, yang ditunjukan dengan DL $<(4-D W)>$ DU atau $(1,5922<$ $1,924>1,7582)$.

\section{Uji Analisis Regresi Berganda}

Berdasarkan ini hasil uji yang telah dilakukan.

Tabel 19. Hasil Analisis Regresi Linier Berganda

\begin{tabular}{|c|c|c|c|c|c|c|}
\hline \multirow[b]{2}{*}{ Mod } & & \multicolumn{2}{|c|}{$\begin{array}{c}\text { Unstandardized } \\
\text { Coefficients }\end{array}$} & \multirow{2}{*}{$\begin{array}{c}\begin{array}{c}\text { Standardized } \\
\text { Coefficients }\end{array} \\
\text { Beta }\end{array}$} & \multirow[b]{2}{*}{$\mathrm{t}$} & \multirow[b]{2}{*}{ Sig. } \\
\hline & & $B$ & Std. Error & & & \\
\hline \multirow[t]{5}{*}{1} & (Constant) & 2,561 & 2,071 & & 1,237 & ,219 \\
\hline & X1 & ,049 & 080, & ,053, & 614, & ,541, \\
\hline & $\times 2$ & ,485 & , 145 & ,371 & 3,345 & ,001 \\
\hline & X3 & ,012 & ,115 & 011 & , 106 & ,916 \\
\hline & $\mathrm{X} 4$ & , 420 & , 100 & ,386 & 4,186 &, 000 \\
\hline
\end{tabular}

Sumber: Hasil olah data primer, 2020.

Selanjutnya, hasil dari koefisien regresi di atas menghasilkan persamaan regresi sebagai berikut :

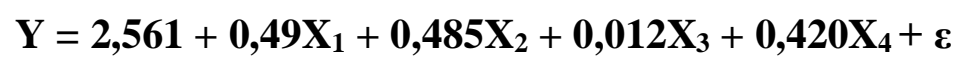

Hasil ini selanjutnya akan dipadukan dengan hipotesis yang telah disusun dan menghasilkan temuan sebagai berikut.

a. $H_{1}$ : Jenjang Pendidikan berpengaruh secara positif dan signifikan terhadap penerapan akuntansi pada UMKM. Hasil pengujian menunjukan bahwa variabel jenjang pendidikan memiliki nilai t hitung sebesar 0,541 dengan nilai signifikansi sebesar 0,541 > 0,05 . Hasil ini menunjukan bahwa variabel jenjang pendidikan tidak berpengaruh terhadap penerapan akuntansi bagi UMKM. Sehingga, kesimpulan ini bermakna bahwa $\mathbf{H}_{\mathbf{1}}$ ditolak. Hasil penelitian ini sejalan dengan hasil penelitian sebelumnya oleh Tuti dan dwijayanti (2016) yang membuktikan bahwa pendidikan terakhir pemilik/manajer tidak berpengaruh signifikan terhadap penggunaan informasi akuntansi pada UMKM. 
b. $\mathrm{H}_{2}$ : Skala Usaha berpengaruh secara positif dan signifikan terhadap penerapan akuntansi pada UMKM. Hasil pengujian menunjukan bahwa variabel skala usaha memiliki nilai t hitung sebesar 0,001 dengan nilai signifikansi sebesar 0,001 <0,05. Hasil ini menunjukan bahwa variabel skala usaha terbukti berpengaruh signifikan terhadap penerapan akuntansi bagi UMKM. Sehingga, kesimpulan ini bermakna bahwa $\mathbf{H}_{2}$ diterima. Hasil penelitian ini sejalan dengan hasil penelitian sebelumnya oleh Yasa, Herawati dan Sulindawati (2017) mengenai skala usaha menunjukkan bahwa skala usaha berpengaruh positif dan signifikan terhadap penggunaan informasi akuntansi pada UMKM.

c. $\mathrm{H}_{3}$ : Lama Usaha berpengaruh secara positif dan signifikan terhadap penerapan akuntansi pada UMKM. Hasil pengujian menunjukan bahwa variabel lama usaha memiliki nilai t hitung sebesar 0,916 dengan nilai signifikansi sebesar 0,916 >0,05. Hasil ini menunjukan bahwa variabel lama usaha tidak berpengaruh terhadap penerapan akuntansi bagi UMKM. Hasil temuan ini menyimpulkan bahwa $\mathbf{H}_{\mathbf{3}}$ ditolak. Hasil penelitian ini bermakna bahwa lamanya usaha belum dapat menjamin pelaku UMKM bersedia melakukan penerapan akuntansi untuk pengembangan usahanya.

d. $\mathrm{H}_{4}$ : Pelatihan Akuntansi berpengaruh secara positif dan signifikan terhadap penerapan akuntansi pada UMKM. Hasil pengujian menunjukan bahwa variabel pelatihan akuntansi memiliki nilai t hitung sebesar 0,000 dengan nilai signifikansi sebesar $0,000<0,05$. Hasil ini menunjukan bahwa variabel pelatihan akuntansi terbukti berpengaruh signifikan terhadap penerapan akuntansi bagi UMKM. Sehingga, kesimpulan ini bermakna bahwa $\mathbf{H}_{\mathbf{4}}$ diterima. Hasil penelitian ini sejalan dengan hasil penelitian sebelumnya oleh Finishia, et al. (2019) yang menunjukkan bahwa pelatihan akuntansi pemilik/manajer berpengaruh positif dan signifikan terhadap penggunaan informasi akuntansi pada UMKM.

\section{Uji Kelayakan Model (Uji F)}

Apabila nilai prob. F hitung (ouput ditunjukkan pada kolom sig.) lebih kecil dari tingkat kesalahan/error (alpha) 0,05 (yang telah ditentukan), maka dapat dikatakan bahwa model regresi yang diestimasi telah layak, sedangkan apabila nilai prob. F hitung lebih besar dari tingkat kesalahan 0,05, maka dapat dikatakan bahwa model regresi yang diestimasi tidak layak (Ghozali, 2013).

Tabel 20. Hasil Uji F

\begin{tabular}{|c|c|c|c|c|c|c|}
\hline Model & & Sum of Squares & $\mathrm{df}$ & Mean Square & $\mathrm{F}$ & Sig. \\
\hline \multirow[t]{3}{*}{1} & Regression & 1048,248 & 4 & 262,062 & 26,091 &, $000^{\mathrm{b}}$ \\
\hline & Residual & 954,192 & 95 & 10,044 & & \\
\hline & Total & 2002,440 & 99 & & & \\
\hline \multicolumn{7}{|c|}{ a. Dependent Variable: Y } \\
\hline \multicolumn{7}{|c|}{ b. Predictors: (Constant), X4, X1, X2, X3 } \\
\hline
\end{tabular}

Sumber: Hasil olah data primer, 2020.

Tabel anova di atas menunjukkan bahwa nilai $\mathrm{F}$ hitung $=26,091$ dengan tingkat probabilitas $0,000<0.05$, sehingga hasil ini disimpulkan bahwa model regresi yang digunakan penelitian ini telah layak.

Koefisien Determinasi $\left(\mathbf{R}^{2}\right)$

Koefisien determinasi diilihat dari besarnya nilai Adjusted $R$ Square untuk mengetahui apakah variabel dependen dapat dijelaskan dengan variabel-variabel independen. 
Tabel 21. Hasil Uji Koefisien Determinasi

\begin{tabular}{llcrr}
\hline Model & $\mathrm{R}$ & $\mathrm{R}$ Square & Adjusted R Square & $\begin{array}{c}\text { Std. Error of the } \\
\text { Estimate }\end{array}$ \\
\hline 1 &, $705^{\mathrm{a}}$ &, 498 &, 476 & 3,25423 \\
\hline a. Predictors: (Constant), XD, XC, XA, XB & & \\
Sumber: Hasil olah data primer, 2020.
\end{tabular}

Sumber: Hasil olah data primer, 2020.

Berdasarkan tabel 21. Di atas, nilai Adjusted $R$ Square sebesar 0,503 yang menunjukkan bahwa kemampuan variabel independen mempengaruhi variabel dependen sebesar 47,6\%, dan masih ada $52,4 \%$ yang dapat diterangkan oleh variabel-variabel lain yang tidak digunakan pada penelitian ini. Hasil temuan ini juga membuktikan bahwa skala usaha dan pelatihan akuntansi memiliki hubungan yang erat dengan penerapan akuntansi. Umur perusahaan juga mempengaruhi penerapan akuntansi, semakin lama UMKM beroperasi, maka akan terlihat pula eksistensi serta pengalaman pemilik/manajernya, sehingga dibutuhkan penerapan akuntansi untuk menjaga kelangsungan usaha UMKM tersebut. Selain itu, pelatihan akuntansi juga akan mempengaruhi penerapan akuntansi, semakin banyak pemilik/manajer mengikuti pelatihan akuntansi akan meningkatkan pemahaman terkait pentingnya penerapan akuntansi, sehingga penerapan akuntansi akan semakin banyak digunakan dan diterapkan guna mempertahankan, mengelola dan menganalisis usaha UMKM tersebut. Uji berikutnya disarankan untuk mempertimbangkan seluruh variabel yang tidak dijelaskan dalam penelitian ini yang mungkin mempengaruhi penerapan akuntansi dan juga menggunakan sampel yang lebih banyak, seperti variabel regulasi pemerintah, sosialisasi dan akses pendanaan.

\section{SIMPULAN}

Berdasarkan hasil analisis dan pembahasan yang telah dilakukan serta didukung dengan teori-teori yang melandasi, maka ditemukan bahwa jenjang pendidikan dan lama usaha tidak berpengaruh terhadap penerapan akuntansi pada UMKM di Provinsi Daerah Istimewa Yogyakarta. Sedangkan skala usaha dan pelatihan akuntansi berpengaruh positif dan signifikan terhadap penerapan akuntansi pada UMKM di Provinsi Daerah Istimewa Yogyakarta. Temuan ini membuktikan bahwa skala usaha dan pelatihan akuntansi memiliki hubungan yang erat dengan penerapan akuntansi. Selain itu, pelatihan akuntansi juga akan mempengaruhi penerapan akuntansi, semakin sering pelaku UMKM diberikan dan mengikuti pelatihan akuntansi, maka hal ini juga akan meningkatkan pengetahuan dan pemahaman terkait penerapan akuntansi. Harapannya agar pelaku UMKM di D.I.Yogyakarta semakin sadar pentingnya penerapan akuntansi guna mempertahankan, mengelola, menganalisis, dan mengembangkan usahanya.

Beberapa saran yang penulis usulkan untuk pihak-pihak yang memiliki kepentingan terhadap peningkatan usaha mikro kecil dan menengah (UMKM) di Provinsi Daerah Istimewa Yogyakarta, terutama Dinas Perindustrian Perdagangan dan Koperasi Daerah Istimewa Yogyakarta untuk mulai meningkatkan memberikan bimbingan tenis dan pelatihan tentang penerapan akuntansi yang berguna untuk mengoperasionalisasikan usahanya. Penelitian selanjutnya disarankan untuk menggunakan sampel yang lebih banyak, sehingga hasil penelitian berikutnya diharapkan lebih mencerminkan realita penerapan akuntansi pada UMKM di Provinsi Daerah Istimewa Yogyakarta.

Penelitian ini juga memiliki kekurangan dan keterbatasan, salah satunya yaitu kuesioner yang disebar tidak terlalu banyak, sehingga data-data yang didapatkan terbatas. Beberapa responden enggan untuk mengisi kuesioner dikarenakan adanya kesibukan. 


\section{DAFTAR PUSTAKA}

Andriani, L., A. T. Atmadja, dan N. K. Sinarwati. (2014). Analisis Penerapan Pencatatan Keuangan Berbasis SAK ETAP Pada Usaha Mikro Kecil Menengah (MKM) (Sebuah Studi Interpretif Pada Peggy Salon). eJournal. Vol. 2. No. 1. p.1-12.

Astiani, Y., dan Sagoro, E. M. (2018). Pengaruh Persepsi Pelaku Usaha Mikro Kecil Dan Menengah Tentang Akuntansi, Pengetahuan Akuntansi, Dan Penggunaan informasi akuntansi Terhadap Penggunaan Informasi Akuntansi. Jurnal Profita: Kajian Ilmu Akuntansi, 6(2).

Darwanto. (2013). Peningkatan Daya Saing UMKM Berbasis Inovasi Dan Kreativitas (Strategi PEnguatan Property Right Terhadap Inovasi Dan Kreativitas). Jurnal Bisnis dan Ekonomi (JBE). Vol.20. No (2). Hal:142-149.

Finishia, Donna Maulita intan dan Leny, Suzan. (2019). Analisis Pengaruh Skala Usaha, Umur Perusahaan dan Latar Belakang Pendidikan Terhadap Penggunaan Informasi Akuntansi. Universitas Telkom, e-proceedings of management. Vol. 6 No. 1 April 2019.

Ghozali, Imam. (2013). Aplikasi Analisis Multivariate dengan Program IBM SPSS 21 Update PLS Regresi. Semarang: Badan Penerbit Universitas Diponegoro.

Ikatan Akuntansi Indonesia (IAI). (2018). Pernyataan Standar Akuntansi Keuangan (PSAK) No 1: Penyajian Laporan Keuangan . Jakarta: IAI

Mertha Jaya, I. M. L. (STIE B. Y. (2019). Perlakuan Akuntansi Sektor Publik Desa. Gorontalo Accounting Journal, 2(1), 1. https://doi.org/10.32662/gaj.v2i1.464

Mertha Jaya, I. made laut, \& Ilahiyah, M. E. I. (2020). Pembinaan Implementasi E-Filing bagi Pelaku UMKM Kerupuk di Kecamatan Gunung Anyar Kota Surabaya. Jurnal Ilmiah Padma Sri Kreshna, 2(2), 14-24. https://doi.org/10.37631/psk.v2i2.198

JAYA, I Made Laut Mertha. (2020). Metode penelitian kuantitatif dan kualitatif: Teori, penerapan, dan riset nyata (cet.1). Yogyakarta: Quadrant.

Kurniawati, E. P., Nugroho, P. I., \& Arifin, C. (2012). Penerapan Akuntansi pada Usaha Mikro Kecil dan Menengah (UMKM). Jurnal Manajemen dan Keuangan, Vol. 10 No.2 (2012).

Lemeshow, (1997), Besar Sampel Dalam Penelitian Kesehatan, Yogyakarta, UGM.

Meiliana, Koes dan A. Fenyta Dewi (2015). Analisis Penggunaan Sistem Informasi Akuntansi Pada Usaha Kecil Dan Menengah Di Yogyakarta. MODUS, Vol.27 (1): 29-40, 2015. ISSN 0852-1875.

Ogston, S. A., Lemeshow, S., Hosmer, D. W., Klar, J., \& Lwanga, S. K. (1991). Adequacy of Sample Size in Health Studies. Biometrics, 47(1), 347. https://doi.org/10.2307/2532527Sinarwati, N. K. (2014). Analisis Faktor-Faktor Yang Mempengaruhi Belum Diterapkannya Pencatatan Keuangan Berbasis Sak, 986-992.

Sujarweni, V. W., \& Jaya, I. M. L. M. (2019a). Community Empowerment in the Development of Geoheritage Tourism Cliff Breksi for Improved Livelihood Villagers Sambirejo Yogyakarta [Pemberdayaan Masyarakat dalam Pengembangan Wisata Warisan Geoheritage Tebing Breksi untuk Peningkatan Taraf Hidup Warga Desa Sambirejo Yogyakarta]. Proceeding of Community Development, 2, 915. https://doi.org/10.30874/comdev.2018.389

Sujarweni, V. W., \& Jaya, I. M. L. M. (2019b). Faktor yang Menentukan (Determinan) Akuntabilitas Keuangan Dana Desa Pasca Penarapan Undang-Undang Nomor 6 tahun 2014. Jurnal Akuntansi, 9(3), 201-218. Sandrayati, Masnila, dan Sari. (2016). Pendidikan dan Pelatihan Dalam Kaitannya Dengan Pemahaman dan Penerapan 
Akuntansi Pada UKM. Prosiding SNAPP2016 Sosial, Ekonomi, dan Humaniora, Vol. 6, No. 1, hlm.800-805.

Sinarwati, Ni Kadek. (2014). Analisis Faktor-Faktor Yang Mempengaruhi Belum Diterapkannya Pencatatan Keuangan Berbasis SAK ETAP di UMKM (Studi Kasus UMKM di Kabupaten Buleleng). SEMINAR NASIONAL RISET INOVATIF II, TAHUN 2014. ISSN : 2339-1553.

Sitoresmi, Linear D dan Fuad. (2013). Faktor-Faktor Yang Mempengaruhi Penggunaan Informasi Akuntansi Pada Usaha Kecil Dan Menengah (Studi Pada Kub Sido Rukun Semarang). Diponegoro Journal of Accounting, Volume 2, Nomor 3, Tahun 2013, Halaman 1-13 ISSN (Online): 2337-3806.

Solovida, Grace Tianna. (2010). Faktor-faktor yang Mempengaruhi Penyiapan dan Penggunaan Informasi Akuntansi pada Perusahan Kecil dan Menengah di Jawa Tengah. Jurnal Prestasi, Vol. 6 No. 1. Juni.

Sujarweni, V. Wiratna dan Jaya, IMLM. (2019). Determining Factor Of Financial Accountability Post-Village Implementation Of Law Number 6 Of 2014. Jurnal Akuntansi. Vol. 9, No.3 2019. Hal. 201-218. DOI : https://doi.org/10.33369/j.akuntansi.9.3.201-218.

Sungkono (2010). Faktor-Faktor Yang Mempengaruhi Cangkupan Penggunaan Informasi Akuntansi pada Koperasi Di Provinsi Daerah Istimewa Yogyakarta. Ebbank, No 2, Vol. 1, Desember.

Tedjasuksmana, B. (2014). Potret Umkm Indonesia Menghadapi Masyarakat Ekonomi Asean 2015. The 7th NCFB and Doctoral Colloquium 2014 Towards a New Indonesia Business Architecture Business And Economic Transformation Towards AEC 2015, 189-202. Tuti, Rias dan S, Patricia Febrina Dwijayanti. (2016). Faktor-Faktor yang Mempengaruhi Pemahaman UMKM dalam Menyusun Laporan Keuangan Berdasarkan SAK ETAP. JURNAL AKUNTANSI KONTEMPORER (JAKO). Vol. 8 No. 2, JULI 2016, Halaman 98-107.

Yasa, I Ketut Swastika Harta, Nyoman Tresna Herawati dan Ni Luh Gede Erni Sulindawati (2017). Pengaruh Skala Usaha, Umur Perusahaan, Pengetahuan dan Akuntansi Terhadap Penggunaan Informasi Akuntansi Pada Usaha Kecil Menengah di Kecamatan Buleleng dengan Ketidakpastian Lingkungan sebagai Variabel Pemoderasi. e-Journal S1 Ak. Universitas Pendidikan Ganesha Jurusan Akuntansi Program S1 (Vol: 8 No: 2 Tahun 2017). 